\title{
Influence of Concrete Properties on Molten Core-Concrete Interaction: A Simulation Study
}

\author{
Jin-yang Jiang, ${ }^{1}$ Ying-jun Yu, ${ }^{1,2}$ Hong-yan Chu, ${ }^{1}$ Wei Sun, ${ }^{1}$ and Yun Gao ${ }^{1}$ \\ ${ }^{1}$ School of Materials Science and Engineering, Southeast University, Nanjing 211189, China \\ ${ }^{2}$ Central Research Institute of Building and Construction Co., Ltd., Beijing, China \\ Correspondence should be addressed to Jin-yang Jiang; jiangjinyang16@163.com
}

Received 20 May 2016; Revised 14 October 2016; Accepted 23 October 2016

Academic Editor: Patrice Berthod

Copyright (c) 2016 Jin-yang Jiang et al. This is an open access article distributed under the Creative Commons Attribution License, which permits unrestricted use, distribution, and reproduction in any medium, provided the original work is properly cited.

\begin{abstract}
In a severe nuclear power plant accident, the molten core can be released into the reactor pit and interact with sacrificial concrete. In this paper, a simulation study is presented that aims to address the influence of sacrificial concrete properties on molten coreconcrete interaction (MCCI). In particular, based on the MELCOR Code, the ferrosiliceous concrete used in European Pressurized Water Reactor (EPR) is taken into account with respect to the different ablation enthalpy and $\mathrm{Fe}_{2} \mathrm{O}_{3}$ and $\mathrm{H}_{2} \mathrm{O}$ contents. Results indicate that the concrete ablation rate as well as the hydrogen generation rate depends much on the concrete ablation enthalpy and $\mathrm{Fe}_{2} \mathrm{O}_{3}$ and $\mathrm{H}_{2} \mathrm{O}$ contents. In practice, the ablation enthalpy of sacrificial concrete is the higher the better, while the $\mathrm{Fe}_{2} \mathrm{O}_{3}$ and $\mathrm{H}_{2} \mathrm{O}$ content of sacrificial concrete is the lower the better.
\end{abstract}

\section{Introduction}

In a simulated core melt accident of nuclear power plant (NPP), a molten pool called corium can melt through the reactor pressure vessel (RPV) and be released to the containment basemat. Driven by the decay power of the fission products and the high temperature, the basemat concrete, which is the last barrier that prevents leakage of the radioactive products into environment in the secondgeneration NPPs, starts to ablate $[1,2]$. Thus, the molten coreconcrete interaction (MCCI) is of great importance in NPP because it may result in leakage of fission products. Previous studies show that the concrete properties have significant impact on MCCI [1-6]. In the third-generation NPPs, such as European Pressurized Water Reactor (EPR) [7], a core catcher is introduced to encase the corium, through which the integrity of the containment is preserved. Moreover, a specific ferrosiliceous sacrificial concrete containing both siliceous and hematite aggregates is employed in the reactor pit of EPR. The role of the sacrificial concrete is to adjust the properties of the corium released from RPV in terms of the interaction between them (MCCI). An investigation carried out by Chu et al. [8] has recently presented a systematic study on thermal properties of ferrosiliceous sacrificial concrete subjected to high temperatures, and another report focusing on the mechanical and physicochemical properties of ferrosiliceous concrete at high temperatures has also been recently published [9]. However, the ablation behavior or MCCI of ferrosiliceous concrete has not been studied in these literatures.

Wang et al. [10] have conducted a simulation investigation on core thermal response during a station blackout initiated severe accident in China pressurized reactor (CPR1000) using MELCOR Code, and the safety of the reactor core has been assessed. Nie [11] has made a systematic research on temporary melt retention in the reactor pit of EPR and has pointed out that, for a large breach loss of coolant accident scenario in the EPR, $1.20 \times 10^{5} \mathrm{~kg}$ of metallic melt and 1.85 $\times 10^{5} \mathrm{~kg}$ of oxidic melt are released in the reactor pit, and the decay heat decreases from $32 \mathrm{MW}$ ( $3 \mathrm{~h}$ after scram) to $20 \mathrm{MW}$ $(30 \mathrm{~h}$ after scram). Nevertheless, the concrete used in the CPR1000 was not the ferrosiliceous sacrificial concrete. Due to the complexity of MCCI, information on this phenomenon is still limited and needs to be updated. 


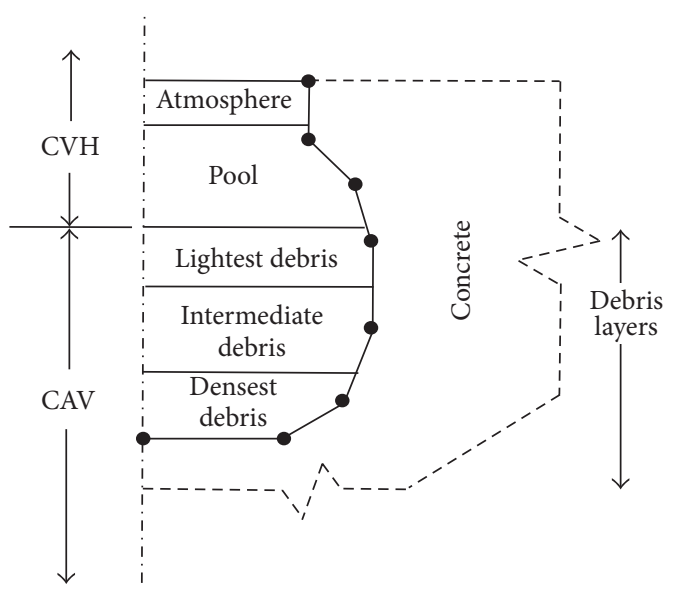

FIGURE 1: The cavity contents and boundary conditions [12].

This paper focuses on the influence of ferrosiliceous concrete properties on the MCCI, including the concrete ablation enthalpy and the $\mathrm{Fe}_{2} \mathrm{O}_{3}$ and $\mathrm{H}_{2} \mathrm{O}$ contents. In the work, a simulation study is performed based on the MELCOR Code used for CPR1000. The calculation model is established by replacing the concrete cavity of a $1000 \mathrm{MW}$ pressurized reactor (CPR1000) by the EPR reactor pit which employed the special ferrosiliceous sacrificial concrete. In essence, it is assumed that the interaction is induced by a typical small break loss of coolant severe accident sequence (SBLOCA) of the CPR1000, but the concrete cavity in the current study has been replaced by the ferrosiliceous sacrificial concrete cavity.

\section{Main Assumptions for the Calculation}

MELCOR is a fully integrated, engineering-level computer code that consists of various modules and packages [12]. The MELCOR Cavity (CAV) package models the attack of hot (often molten) core materials on the basemat concrete [14], and the cavity contents and boundary conditions are shown in Figure 1.

In the CAV package, two modes can be selected for the configuration of the core melt, that is, enforced mixing or enforced stratification. The enforced mixing is the simplest mode which considers the melt being a single layer. For the enforced stratification mode, the configuration of the melt is determined by the specific density of each layer. The most common structure is a three-layer configuration, where a metallic layer (MET) exists between the light oxide layer (LOX) and the heavy oxide layer (HOX). Another factor influencing the configuration of core melt is the rising gas bubbles generated by concrete decomposition, which promotes the mixing of different layers. In Sections 3.1 and 3.2, the configurations of core melt are assumed to be enforced mixing. In Section 3.3, with respect to the impact of rising gas bubbles, the configuration of core melt is assumed to be enforced stratification that shall address the influence of $\mathrm{H}_{2} \mathrm{O}$ content. The ablation behavior of sacrificial concrete depends on the heat transferred from melt to it. The heat in the cavity comes from two sources, that is, the decay power from fission products (FP) and the chemical reaction taking place in the melt. The heat is transferred either through the top surface of the debris or to the concrete basemat and sidewalls, as determined by the thermal resistances.

In regard to the thermal resistance at MCCI, there are also two models to be selected, that is, the gas film model and the slag film model. For the gas film model, the dominant heat transfer mode is bubble-enhanced heat transfer determined by Greene correlation [15]. For the slag film model, intermittent melt-concrete contact results in periodic growth and removal of slag from the interface, and thus a modified version of the Kutateladze correlation [16] is used for bubbling heat transfer coefficient. In addition, a solid crust may be formed at the interface between sacrificial concrete and melt with heat transfer by thermal conduction. The solid crust hinders the contact of melt with concrete and decreases the heat transfer from melt to sacrificial concrete. In the paper, the slag film model is selected for both bottom and radial thermal resistance, because, under the postulated severe accident, superficial gas velocity is much lower and cannot form a stable gas film [17].

Another important parameter that affects sacrificial concrete ablation is the temperature at MCCI, which is defined as the ablation temperature of sacrificial concrete in MELCOR. The ablation temperature of ferrosiliceous sacrificial concrete used in the study is $1453 \mathrm{~K}$, according to [1].

A typical small break loss of coolant severe accident sequence (SBLOCA) of the $1000 \mathrm{MW}$ EPR NPP is assumed in this study. Before the accident, the EPR operates at full power with the thermal power of $3426 \mathrm{MW}$ and the average coolant temperature of $566 \mathrm{~K}$. Time zero in the calculation corresponds to the time of the reactor scram. Upon a stable calculation, that is, $-550 \sim 0 \mathrm{~s}$, the break initiates. No safety intervention is applied during the accident process. At $4360 \mathrm{~s}$, the RPV was melted through. After that, the corium was poured into the sacrificial concrete pit mainly at two periods, 4360 5000 s and 7455 9767 s, and the mass of the corium in these two periods is $0.72 \times 10^{5}$ and $0.54 \times 10^{5} \mathrm{~kg}$, respectively. The total mass of corium released to the reactor pit is about $1.26 \times 10^{5} \mathrm{~kg}$.

The MELCOR decay heat package models the decay heat power resulting from the radioactive decay of fission products. In the study, the whole decay heat power was set according the CPR1000. The evolution of decay heat, heat loss to sacrificial concrete, and heat loss from debris surface is shown in Figure 2. And the decay heat, heat loss to sacrificial concrete, and heat loss from debris surface are not changed after $14500 \mathrm{~s}$.

The material in reactor pit is made up of the ferrosiliceous sacrificial concrete with high content of $\mathrm{Fe}_{2} \mathrm{O}_{3}$. The composition and properties of sacrificial concrete input for calculation are shown in Tables 1 and 2, respectively. The geometry of the initial concrete cavity is cylindrical with a height of $4.95 \mathrm{~m}$, radius of $3.075 \mathrm{~m}$, basemat axial thickness of $0.45 \mathrm{~m}$, and radial thicknesses of $0.55 \mathrm{~m}$. The calculations are processed until axial melt-through. In addition, the maximum radius ablation depth is around $0.31 \mathrm{~m}$.

In the paper, we supposed that the ablation behavior of sacrificial concrete was isotropic. An investigation by Sevón 
TABLE 1: The composition of ferrosiliceous concrete [1].

\begin{tabular}{lcccccccc}
\hline Composition & $\mathrm{SiO}_{2}$ & $\mathrm{Fe}_{2} \mathrm{O}_{3}$ & $\mathrm{CaO}$ & $\mathrm{MgO}$ & $\mathrm{Al}_{2} \mathrm{O}_{3}$ & $\mathrm{CO}_{2}$ & $\mathrm{H}_{2} \mathrm{O}_{\text {EVAP }}$ & $\mathrm{H}_{2} \mathrm{O}_{\text {CHEM }}$ \\
\hline Wt. (\%) & 44.4 & 32.3 & 12.4 & 1.0 & 3.2 & 2.3 & 2.4 & 2.0 \\
\hline
\end{tabular}

TABLE 2: The properties of ferrosiliceous concrete [1].

\begin{tabular}{lcccc}
\hline Properties & Density $/\left(\mathrm{kg} / \mathrm{m}^{3}\right)$ & Solidus temperature $/ \mathrm{K}$ & Liquidus temperature $/ \mathrm{K}$ & Ablation temperature $/ \mathrm{K}$ \\
\hline Values & 2620 & 1433 & 1703 & 1453 \\
\hline
\end{tabular}

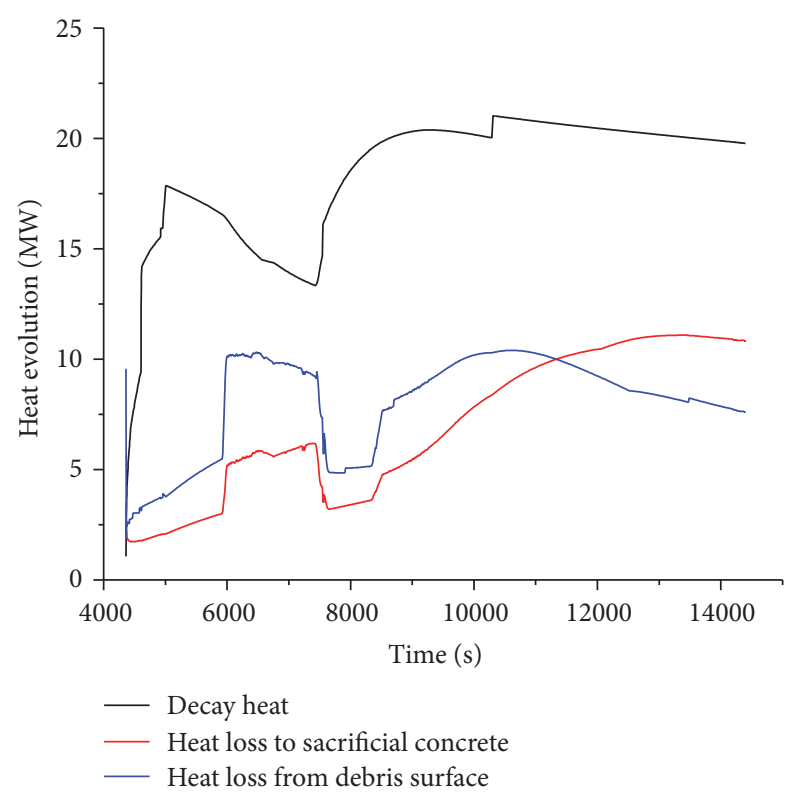

Figure 2: The evolution of decay heat, heat loss to sacrificial concrete, and heat loss from debris surface in the calculation.

et al. [2] has shown that an anisotropic ablation pattern is observed for ferrosiliceous sacrificial concrete, but this result is based on small scale of MCCI. On the whole, however, the isotropic assumption was reasonably taken to evaluate the MCCI as it maximizes basemat ablation.

\section{Results and Discussion}

3.1. Ablation Enthalpy. Sacrificial concrete ablation enthalpy quantifies the heat required to convert a unit mass of virgin sacrificial concrete into condensed and gaseous decomposition products at the specified ablation temperature. Ablation enthalpy not only modifies the sacrificial concrete ablation heat but also changes the energy balance of ablation. For ferrosiliceous sacrificial concrete, the value of $1730 \mathrm{~kJ} / \mathrm{kg}$ could be assigned as its ablation enthalpy, according to literature [18]. In this study, an increased ablation enthalpy of $10 \%, 20 \%$, and $30 \%$ shall be performed to address its effect on the MCCI behavior.

As shown in Figure 3, the sacrificial concrete ablation rate shows a "peak-valley" tendency which may result from a "form-melt-reform-remelt" process of the crust. As the sacrificial concrete ablation enthalpy increases, the ablation rate decreases. In consequence, the melt-through time increases.

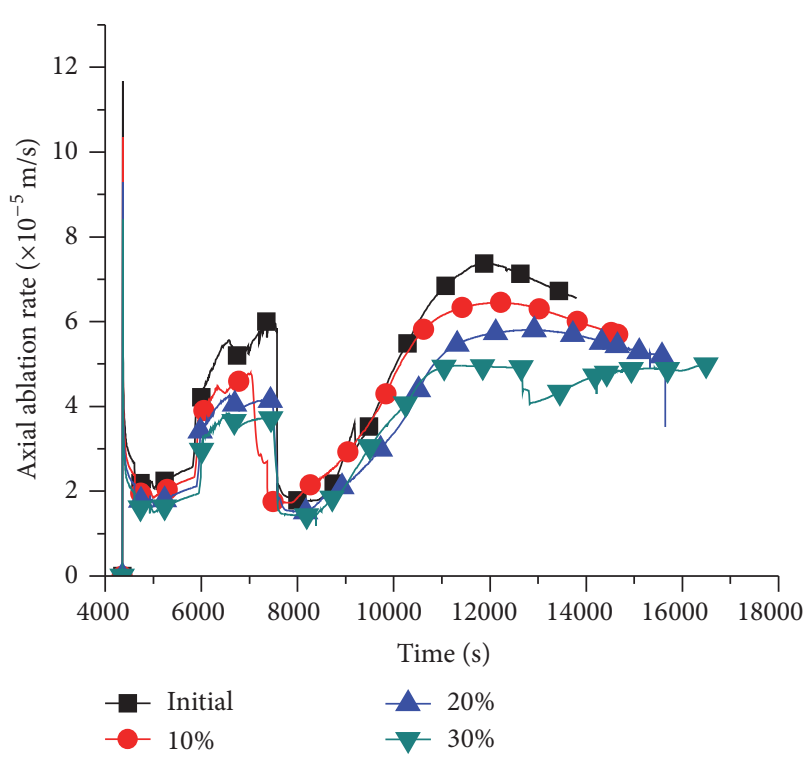

FIGURE 3: Sacrificial concrete ablation rate under different ablation enthalpy.

At the elapsed time of 4360 5800 s and 7300 8700 s, the low and stable ablation rate of $2.2 \times 10^{-5} \mathrm{~m} / \mathrm{s}$ can be detected, which is attributed to the crust formed at the interface. Thereafter, the ablation rate increases rapidly. The maximum ablation rate of the initial (control) sacrificial concrete is 7.0 $\times 10^{-5} \mathrm{~m} / \mathrm{s}$. When the ablation enthalpy increases by $30 \%$, the value of that is $4.7 \times 10^{-5} \mathrm{~m} / \mathrm{s}$. Besides that, the melt-through time of the initial sacrificial concrete is $9442 \mathrm{~s}$. When the ablation enthalpy increases by $10 \%, 20 \%$, and $30 \%$, the meltthrough time is 10332 s, 11283 s, and 12245 s, respectively. As the melt is released from RPV to the pit, the melt temperature displays a rapid increase, as shown in Figure 4, the result of which is due to the decay heat released by fission products. The temperature decreases gradually after $5800 \mathrm{~s}$ upon the mixing of cold sacrificial concrete decomposition products with the melt. Similar to the sacrificial concrete ablation rate, the hydrogen generation rate also shows a "peak-valley" tendency, as illustrated in Figure 5. Minor discrepancies can be detected for the sacrificial concretes with varying ablation enthalpy. It might be due to the longer melt-through time for sacrificial concrete with larger ablation enthalpy. Thus, if the ablation enthalpy of sacrificial concrete is increased through mix design, then the melt-through time is prolonged, which is paramount for nuclear accident mitigation. 


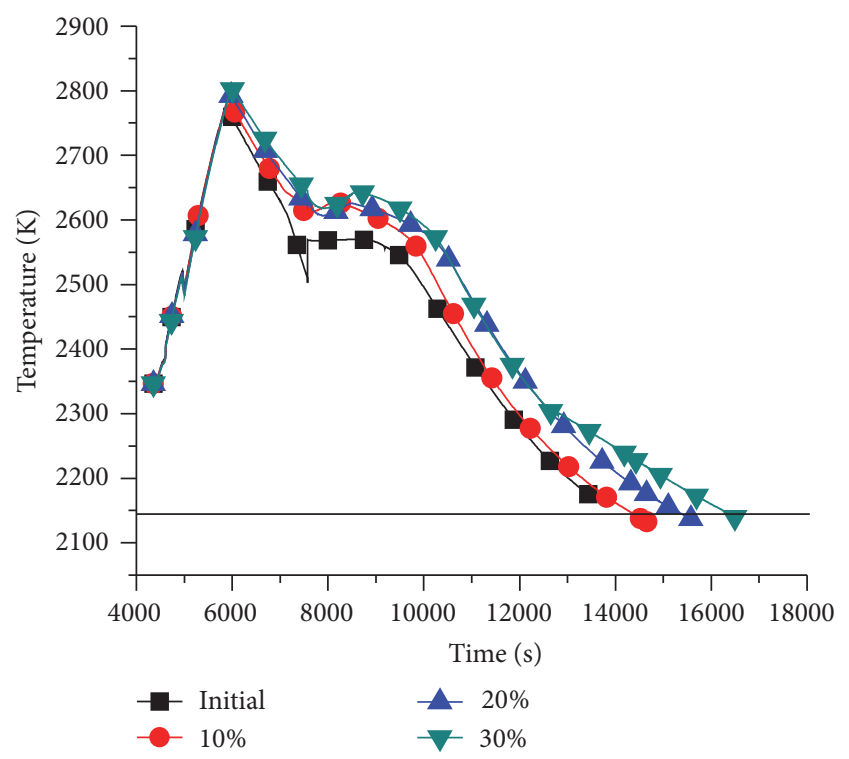

FIgURE 4: Temperature under different ablation enthalpy.

Past studies have suggested that concrete ablation in essence depends on the heat transfer from the melt pool to concrete. In this way, the concrete ablation rate can be expressed as follows [13]:

$$
v=\frac{\dot{Q}}{\rho A \Delta H},
$$

where $\dot{Q}$ is the heat flux to concrete, $\rho$ is the concrete density, $\Delta H$ is the concrete decomposition enthalpy, and $A$ is the area of the ablating concrete. In practice, the heat conducted into concrete can be ignored with respect to the low thermal conductivity of concrete. Equation (1) suggests that when the concrete decomposition enthalpy increases, the concrete ablation rate decreases. In other words, upon the same heat flux, the concrete will be ablated more for the concrete with smaller decomposition enthalpy. Thus, as the mixed cold concrete decomposition products increase, the melt temperature decreases faster. Meanwhile, since $\mathrm{H}_{2} \mathrm{O}$ is produced from the concrete decomposition, the hydrogen generation rate is closely related. As shown in Figure 5(b), the tendency of hydrogen generation rate is similar to the sacrificial concrete ablation rate.

3.2. $\mathrm{Fe}_{2} \mathrm{O}_{3}$ Content. As aforementioned, the sacrificial concrete is critical to the core catcher in EPR pit. It mainly contains $\mathrm{Fe}_{2} \mathrm{O}_{3}$ and $\mathrm{SiO}_{2}$ with the total content reaching $76.7 \%[1,2]$. Previous studies indicated that heat released from the interactions of $\mathrm{Fe}_{2} \mathrm{O}_{3}$ and $\mathrm{SiO}_{2}$ with zirconium accounts for the ablation of concrete [17]. For the sake of illustration, the reaction equations are presented, that is, (2)(4). It can be noted that the heat with the $\mathrm{Fe}_{2} \mathrm{O}_{3}-\mathrm{Zr}$ reaction varies from that with the $\mathrm{SiO}_{2}-\mathrm{Zr}$ reaction, especially at the temperature above $2143 \mathrm{~K}$. Thus, the $\mathrm{Fe}_{2} \mathrm{O}_{3}$ content shall be of paramount importance for the MCCI. The $\mathrm{Fe}_{2} \mathrm{O}_{3}$ content in ferrosiliceous sacrificial concrete is around $32 \sim 36 \%$ [1]. In the KAPOOL tests, this value was chosen at $48 \%$ [3]. In this paper, the $\mathrm{Fe}_{2} \mathrm{O}_{3}$ content is chosen at $32.3 \%, 36 \%$, and $48 \%$. Meanwhile, the $\mathrm{SiO}_{2}$ content is adjusted to ensure the sum of $\mathrm{Fe}_{2} \mathrm{O}_{3}$ and $\mathrm{SiO}_{2}$ at $76.7 \%$.

$$
\begin{aligned}
& \mathrm{Zr}+\mathrm{SiO}_{2} \longrightarrow \mathrm{ZrO}_{2}+\mathrm{Si}+1.6 \mathrm{MJ} / \mathrm{kg} \mathrm{Zr} \\
&(T<2143 \mathrm{~K}) \\
& \mathrm{Zr}+2 \mathrm{SiO}_{2}+4.7 \mathrm{MJ} / \mathrm{kg} \mathrm{Zr} \longrightarrow \mathrm{ZrO}_{2}+2 \mathrm{SiO}(\mathrm{g}) \\
&(T>2143 \mathrm{~K})
\end{aligned}
$$

$3 \mathrm{Zr}+2 \mathrm{Fe}_{2} \mathrm{O}_{3} \longrightarrow 3 \mathrm{ZrO}_{2}+4 \mathrm{Fe}+5.8 \mathrm{MJ} / \mathrm{kg} \mathrm{Zr}$

As shown in Figures 6-8, with the increased $\mathrm{Fe}_{2} \mathrm{O}_{3}$ content, both the sacrificial concrete ablation rate and the hydrogen generation rate increase, while the melt temperature decreases faster. In particular, the maximum sacrificial concrete ablation rate for the $48 \% \mathrm{Fe}_{2} \mathrm{O}_{3}$ content is about 1.4 times that for the $32.3 \% \mathrm{Fe}_{2} \mathrm{O}_{3}$ content. The melt-through time of sacrificial concrete decreases from $9442 \mathrm{~s}$ to $9131 \mathrm{~s}$ to $8193 \mathrm{~s}$. In addition, the maximum temperature difference reaches $223 \mathrm{~K}$, as compared to the concretes of $32.3 \%$ and $48 \%$ $\mathrm{Fe}_{2} \mathrm{O}_{3}$ contents. The mass of generated hydrogen is $102.6 \mathrm{~kg}$ for the sacrificial concrete with $32.3 \% \mathrm{Fe}_{2} \mathrm{O}_{3}$ content. However, sacrificial concrete with $48 \% \mathrm{Fe}_{2} \mathrm{O}_{3}$ content generates slightly less hydrogen, that is, $96.9 \mathrm{~kg}$, the result of which is in line with literature [3].

Figure 9 indicates that the heat loss to sacrificial concrete increases with the increase of $\mathrm{Fe}_{2} \mathrm{O}_{3}$ content. Also, it reveals the reason why the sacrificial concrete ablation rate increases with the increase of $\mathrm{Fe}_{2} \mathrm{O}_{3}$ content. Above $2143 \mathrm{~K}$, the $\mathrm{SiO}_{2}-$ $\mathrm{Zr}$ reaction is endothermic and the $\mathrm{Fe}_{2} \mathrm{O}_{3}-\mathrm{Zr}$ reaction is exothermic. Below $2143 \mathrm{~K}$, the heat released from the $\mathrm{Fe}_{2} \mathrm{O}_{3}-$ $\mathrm{Zr}$ reaction is higher than the $\mathrm{SiO}_{2}-\mathrm{Zr}$ reaction upon the oxidation of same amount of $\mathrm{Zr}$. It should be noted that, in the calculation except the very last instants of MCCI, $\mathrm{SiO}_{2}-\mathrm{Zr}$ interaction is endothermal in the bulk of the pool, as shown in Figures 4 and 7 (the horizontal full line at $2143 \mathrm{~K}$ ). Thus, the higher $\mathrm{Fe}_{2} \mathrm{O}_{3}$ content leads to the higher heat loss to sacrificial concrete. Figure 10 presents that the enthalpy of $\mathrm{SiO}_{2}$ is higher than that of $\mathrm{Fe}_{2} \mathrm{O}_{3}$. At the ablation temperature of $1453 \mathrm{~K}$, the ablation enthalpy shall be lower for the sacrificial concrete with higher $\mathrm{Fe}_{2} \mathrm{O}_{3}$ content. It is another reason for the faster ablation of the sacrificial concrete with higher $\mathrm{Fe}_{2} \mathrm{O}_{3}$ content. Therefore, the melt-through time can be extended by decreasing the $\mathrm{Fe}_{2} \mathrm{O}_{3}$ content in ferrosiliceous sacrificial concrete.

3.3. $\mathrm{H}_{2} \mathrm{O}$ Content. During MCCI, the generated $\mathrm{H}_{2} \mathrm{O}$ from concrete decomposition arises through the melt pool. On one hand, $\mathrm{H}_{2} \mathrm{O}$ can react with the metal in the melt to release $\mathrm{H}_{2}$. On the other hand, the gas bubble stirs the melt, which can facilitate to the heat transfer and the mixing of different layers. In this regard, the $\mathrm{H}_{2} \mathrm{O}$ content is another important factor for MCCI. In this paper, the $\mathrm{H}_{2} \mathrm{O}$ content is chosen at $2 \%$, $4.4 \%$, and $8 \%$ to investigate the related effect on MCCI. The other components are adjusted to maintain the sum of $100 \%$. The enforced stratification is applied for the configuration of the pool. 


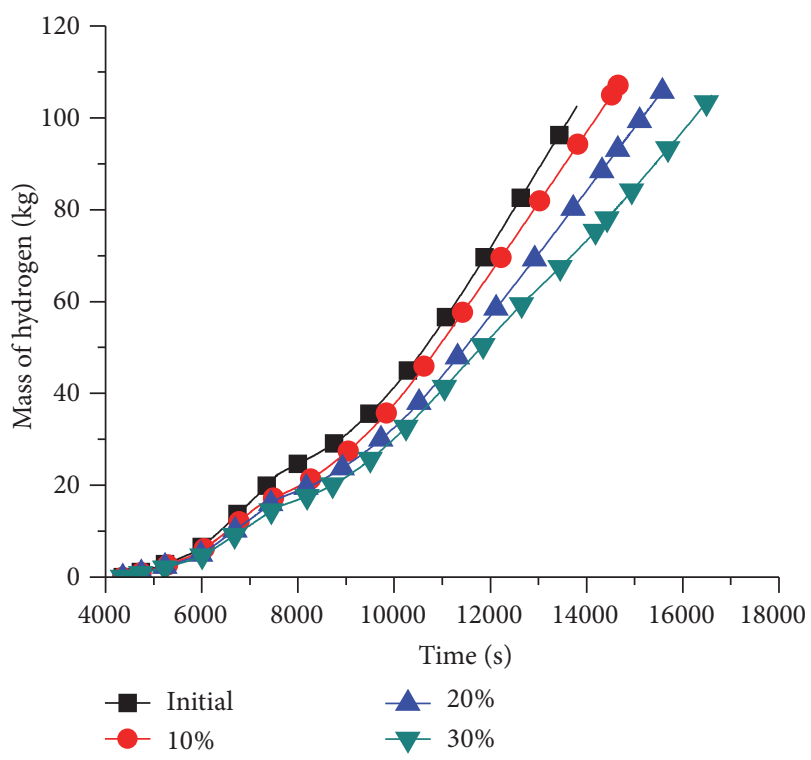

(a) Mass

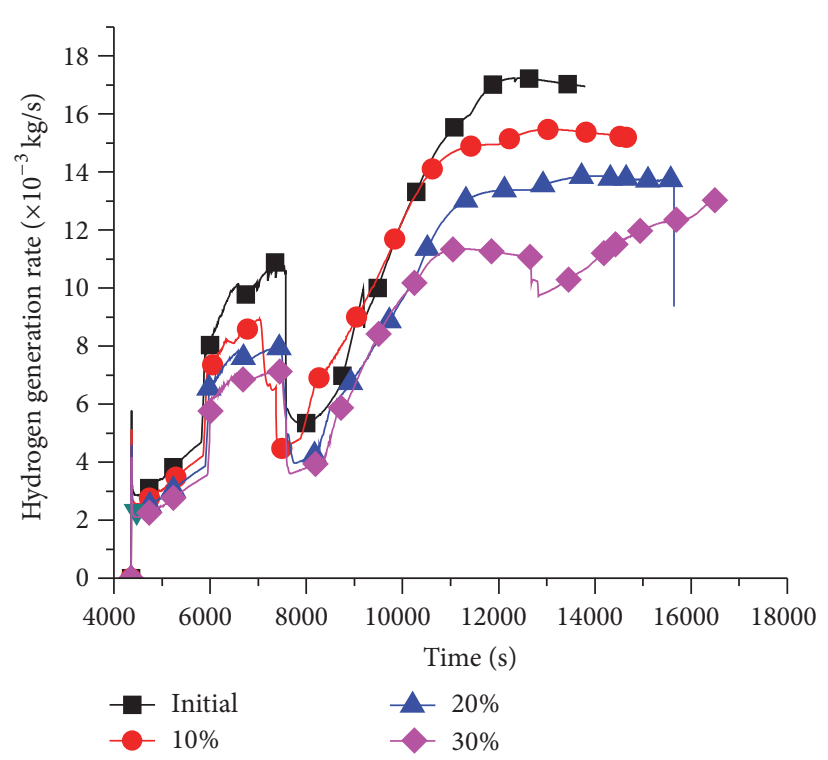

(b) Generation rate

FIGURE 5: Hydrogen mass generation rate under different ablation enthalpy.

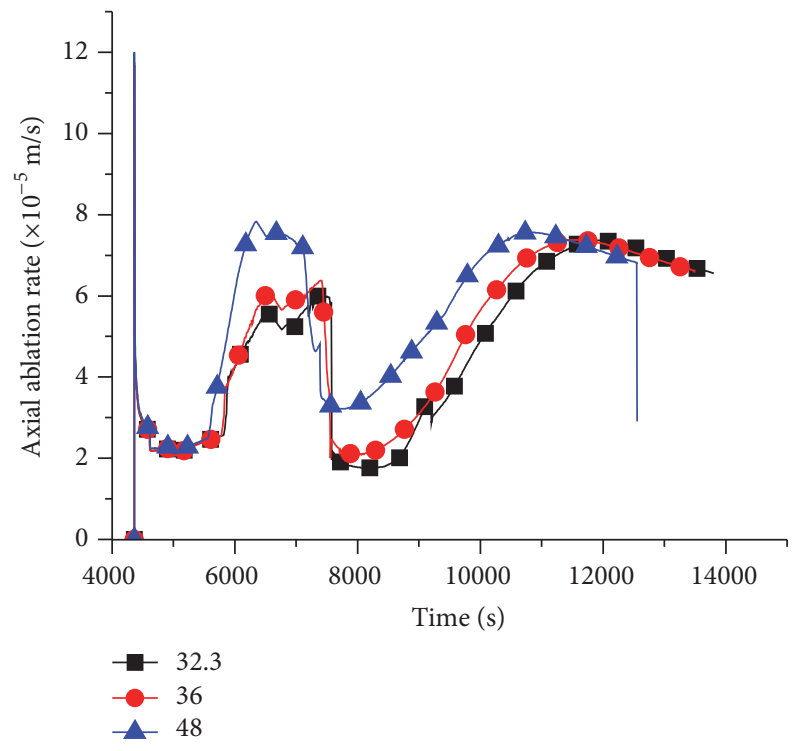

FIGURE 6: Sacrificial concrete ablation rate under different contents of $\mathrm{Fe}_{2} \mathrm{O}_{3}$.

As shown in Figure 11(a), with the increase of $\mathrm{H}_{2} \mathrm{O}$ content, the ablation depth of sacrificial concrete decreases during most period of MCCI. It is noted that, at the elapsed time of $11698 \sim 14446 \mathrm{~s}$, the sacrificial concrete ablation depth for the $4.4 \% \mathrm{H}_{2} \mathrm{O}$ content is larger than that for the $2 \%$ $\mathrm{H}_{2} \mathrm{O}$ content. As shown in Figure 11(b), little difference can be detected for the sacrificial concrete ablation rate before $7730 \mathrm{~s}$. After $7730 \mathrm{~s}$, however, the ablation rate varies sharply after a period of slow ablation due to the appearance and disappearance of the LOX layer. For the sacrificial concrete with $2 \% \mathrm{H}_{2} \mathrm{O}$, the ablation rate increases sharply

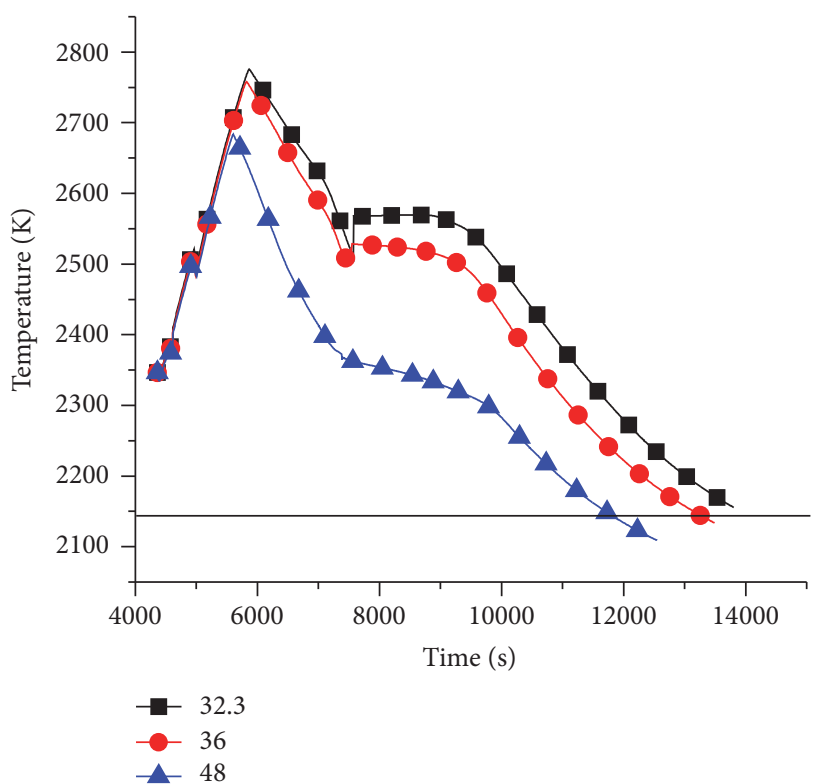

Figure 7: Temperature under different contents of $\mathrm{Fe}_{2} \mathrm{O}_{3}$.

in $11689 \sim 14288 \mathrm{~s}$. It is caused by the sharp increase of heat transferred to sacrificial concrete due to the disappearance of the LOX layer above MET and HOX layers. Thereafter, the sacrificial concrete ablation rate decreases dramatically till $16138 \mathrm{~s}$. The average ablation rate is around $2.80 \times 10^{-5} \sim 2.90 \times$ $10^{-5} \mathrm{~m} / \mathrm{s}$ with a peak value of $1.05 \times 10^{-4} \mathrm{~m} / \mathrm{s}$ till the basemat is melted through. The overall tendency of ablation rate of the $4.4 \% \mathrm{H}_{2} \mathrm{O}$ content is similar to that of the $2 \% \mathrm{H}_{2} \mathrm{O}$ content. Some variations occur $9500 \sim 15343$ s. The maximum ablation rate reaches $7.5 \times 10^{-5} \mathrm{~m} / \mathrm{s}$ for the sacrificial concrete with $4.4 \% \mathrm{H}_{2} \mathrm{O}$ content, lower than that of concrete with $2 \% \mathrm{H}_{2} \mathrm{O}$ 


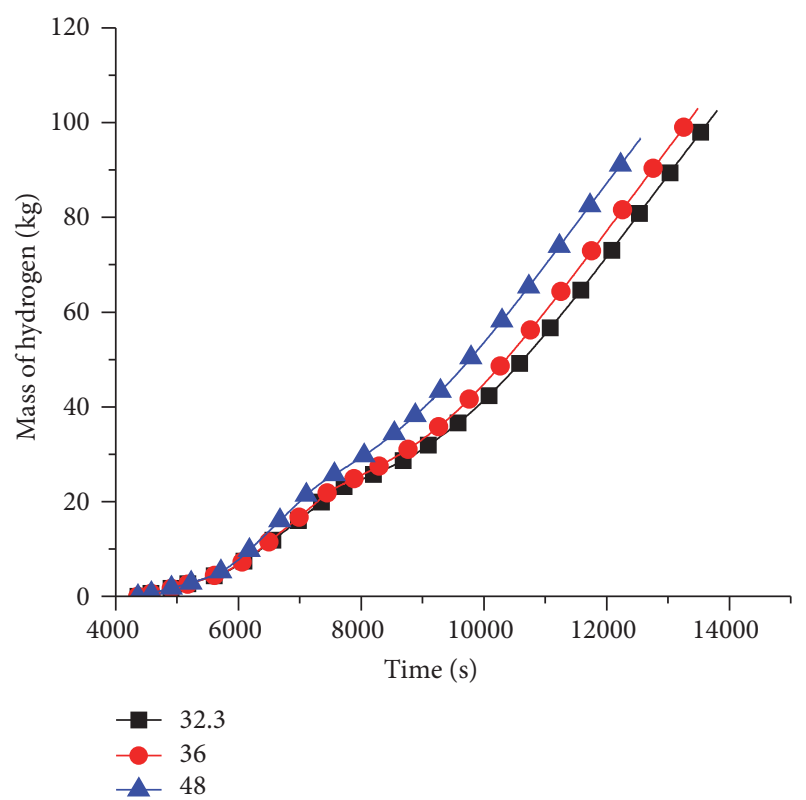

(a) Mass

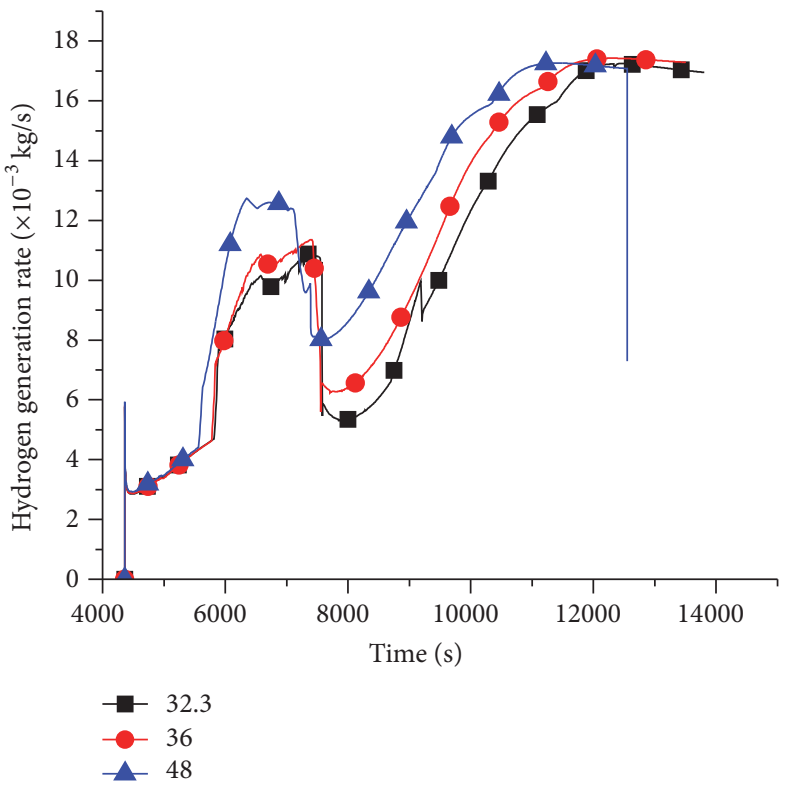

(b) Generation rate

FIgURE 8: Hydrogen mass generation rate under different contents of $\mathrm{Fe}_{2} \mathrm{O}_{3}$.

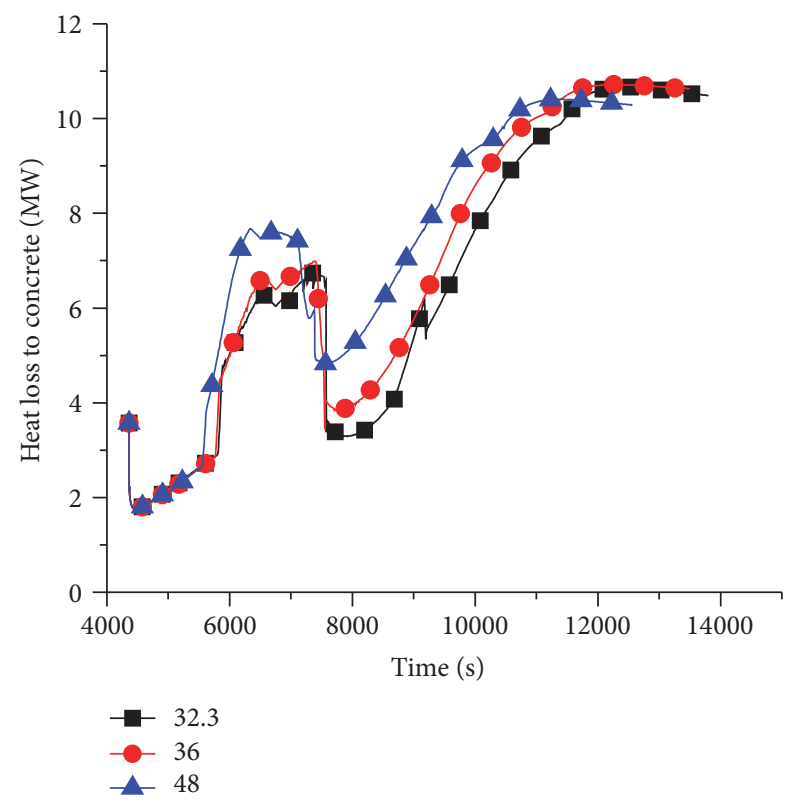

FIgURE 9: Heat loss to concrete under different contents of $\mathrm{Fe}_{2} \mathrm{O}_{3}$.

content. After $15343 \mathrm{~s}$, the ablation rate is $1.9 \sim 3.6 \times 10^{-5} \mathrm{~m} / \mathrm{s}$ and is also lower than that of concrete with $2 \% \mathrm{H}_{2} \mathrm{O}$ content. In addition, the ablation rate with $8 \% \mathrm{H}_{2} \mathrm{O}$ content is always at a low value of $1.33 \sim 1.70 \times 10^{-5} \mathrm{~m} / \mathrm{s}$ till $23480 \mathrm{~s}$. It increases sharply till the sacrificial concrete is melted through due to the disappearance of the LOX layers after $23480 \mathrm{~s}$. The meltthrough time increases from $16005 \mathrm{~s}$ to $18130 \mathrm{~s}$ to $23622 \mathrm{~s}$ for the sacrificial concrete with $2 \%, 4.4 \%$, and $8 \% \mathrm{H}_{2} \mathrm{O}$ content, respectively. Similar results were reported by Gencheva et al. [19]. On the whole, with the increase of $\mathrm{H}_{2} \mathrm{O}$ content, the

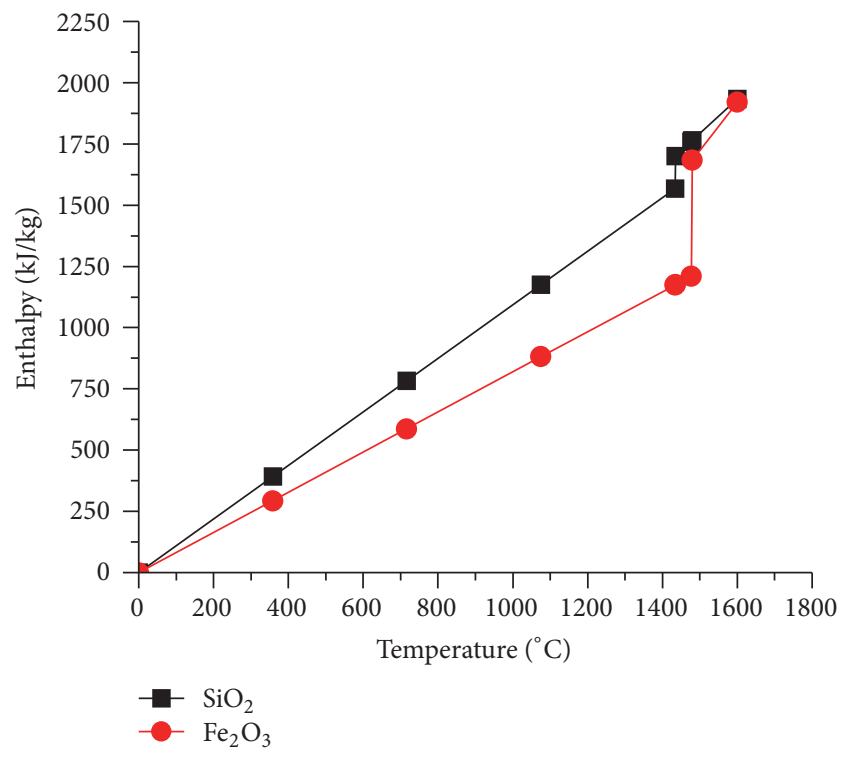

FIGURE 10: Enthalpy of quartz $\left(\mathrm{SiO}_{2}\right)$ and hematite $\left(\mathrm{Fe}_{2} \mathrm{O}_{3}\right)$ [13].

ablation rate of sacrificial concrete was decreased. Maybe that was because the bubbling caused by the higher $\mathrm{H}_{2} \mathrm{O}$ content could result in mixing and thus lead to an even slower axial ablation rate [20].

In addition, the temperatures of HOX and MET decrease with the increase of $\mathrm{H}_{2} \mathrm{O}$ content in sacrificial concrete, as illustrated in Figure 12.

As shown in Figure 13, the hydrogen mass and the generation rate of concrete with $8 \% \mathrm{H}_{2} \mathrm{O}$ content are both higher than those of concrete with $2 \%$ and $4.4 \% \mathrm{H}_{2} \mathrm{O}$ content, which differs from its ablation depth and rate. The total mass 


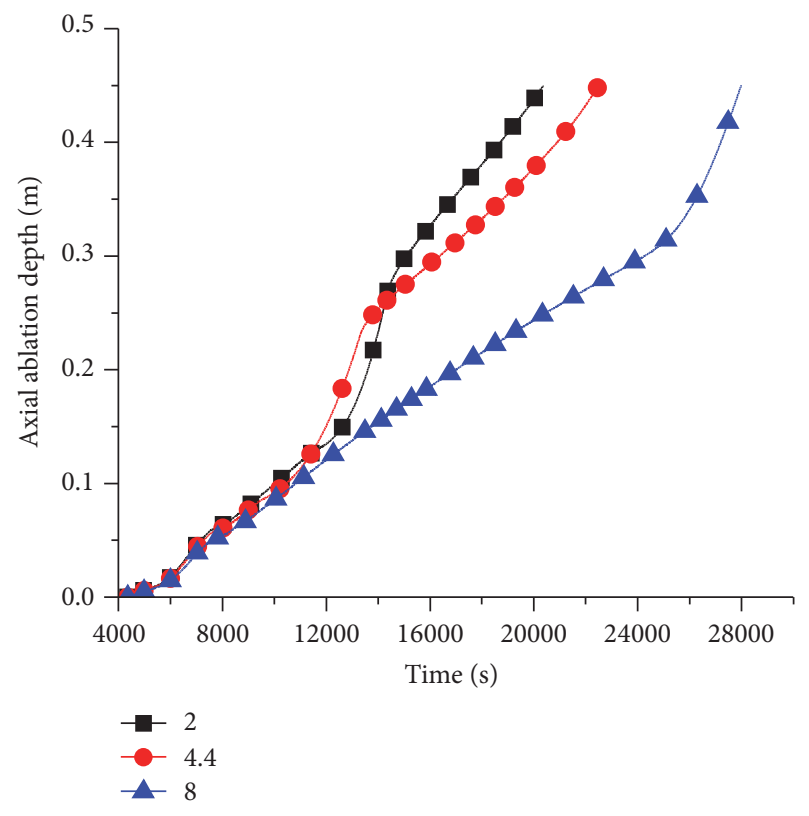

(a)

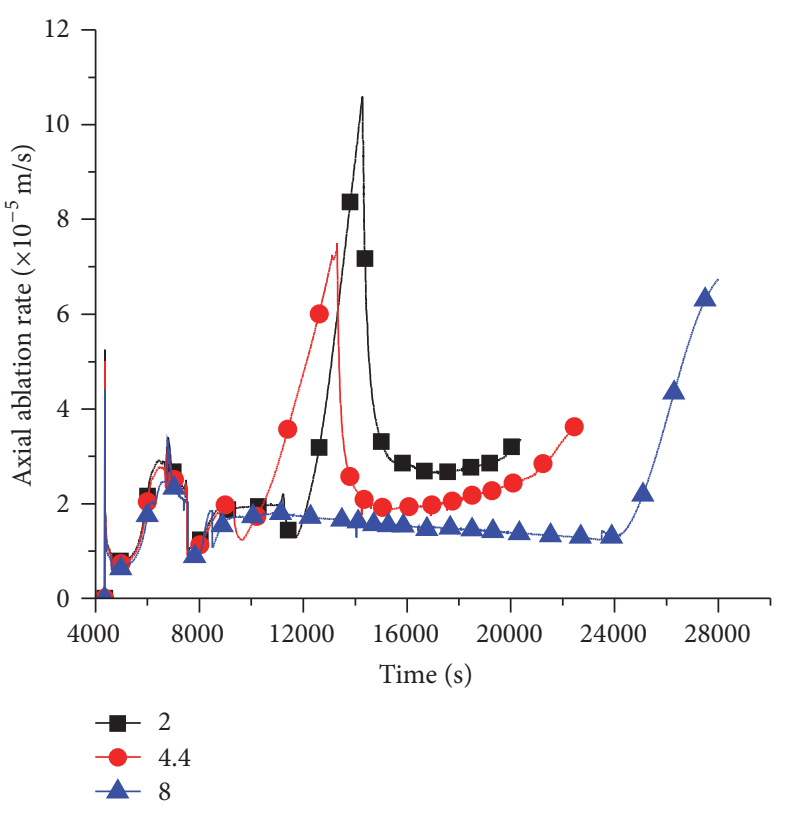

(b)

FIgURE 11: (a) Sacrificial concrete ablation depth and (b) ablation rate under different contents of $\mathrm{H}_{2} \mathrm{O}$ as a function of time.

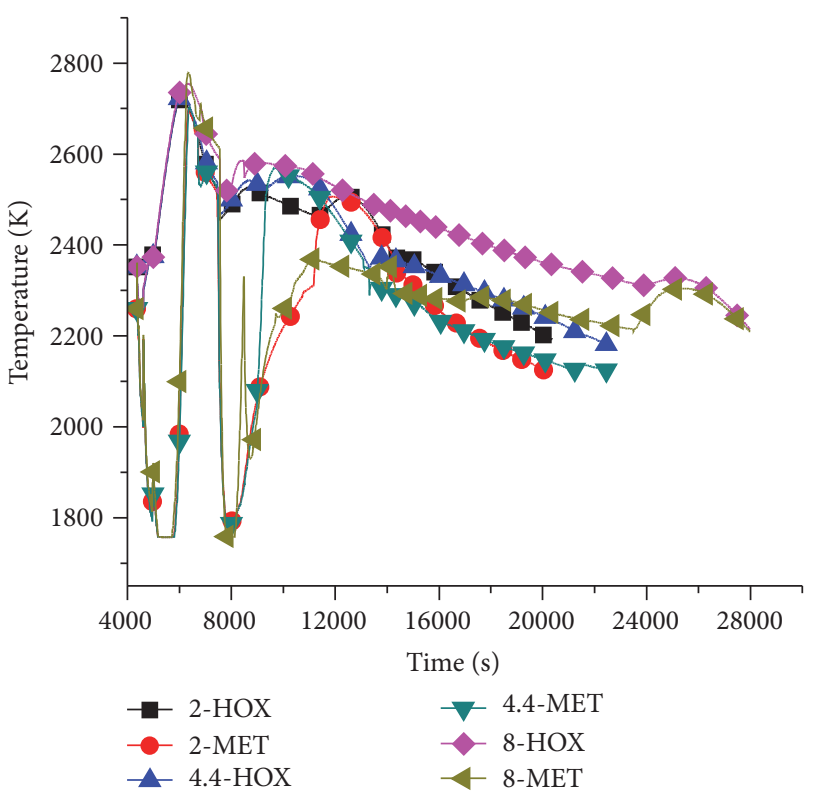

FIGURE 12: Temperature of HOX and MET under different contents of $\mathrm{H}_{2} \mathrm{O}$.

of hydrogen generated for the $8 \% \mathrm{H}_{2} \mathrm{O}$ content is $389.42 \mathrm{~kg}$, and it is 3.6 times of that generated for the $2 \% \mathrm{H}_{2} \mathrm{O}$ content. Therefore, the higher $\mathrm{H}_{2} \mathrm{O}$ content could lead to the increase of $\mathrm{H}_{2}$ explosion possibility in reactor, which affects the safety of NPP.

As shown in Figure 14, the small thickness of LOX varies mildly with the $\mathrm{H}_{2} \mathrm{O}$ content before $7300 \mathrm{~s}$. As the sacrificial concrete ablates, the thickness of LOX for the sacrificial concrete with $2 \% \mathrm{H}_{2} \mathrm{O}$ content increases rapidly at
$11698 \sim 144258 \mathrm{~s}$. The related elapsed time is at $9500 \sim 13231 \mathrm{~s}$ for the sacrificial concrete with $4.4 \% \mathrm{H}_{2} \mathrm{O}$ content, while no LOX layer can be detected until $23480 \mathrm{~s}$ for the sacrificial concrete with $8 \% \mathrm{H}_{2} \mathrm{O}$ content. It might be attributed to the larger mass of heavy $\mathrm{ZrO}_{2}$ generated by the $\mathrm{Zr}-\mathrm{H}_{2} \mathrm{O}$ reaction. The gas mass generated during MCCI increases with the increase of $\mathrm{H}_{2} \mathrm{O}$ content, which results in more heat loss to surface and less heat loss to sacrificial concrete, as can be seen in Figures 15 and 16. Most of all, for the sacrificial concrete with $8 \% \mathrm{H}_{2} \mathrm{O}$ content, the heat loss to surface by generated gas is about 10 times of that to sacrificial concrete ablation. In this regard, the ablation rate decreases with the decrease of $\mathrm{H}_{2} \mathrm{O}$ content. In addition, the LOX MET and HOX hinder heat loss through the surface of melt, as illustrated in Figure 16. The ablation rate increases sharply when the LOX exists. Consequently, the $\mathrm{H}_{2} \mathrm{O}$ content has a big effect on the ablation rate and hydrogen production of MCCI, and the $\mathrm{H}_{2} \mathrm{O}$ content of sacrificial concrete is the lower the better for the safety of nuclear power plant.

In a word, the properties of sacrificial concrete have a crucial impact on the MCCI. In practice, the ablation enthalpy of sacrificial concrete is the higher the better, while the $\mathrm{H}_{2} \mathrm{O}$ and $\mathrm{Fe}_{2} \mathrm{O}_{3}$ content of sacrificial concrete is the lower the better for the safety of NPP and for the nuclear accident mitigation. The simulation investigation has important consulting meaning to the mixture design of the ferrosiliceous sacrificial concrete.

\section{Conclusion}

In this paper, based on the computer code MELCOR, we investigate the effects of sacrificial concrete properties on MCCI, including its ablation enthalpy and contents of $\mathrm{Fe}_{2} \mathrm{O}_{3}$ and $\mathrm{H}_{2} \mathrm{O}$. In particular, the ferrosiliceous concrete used in 


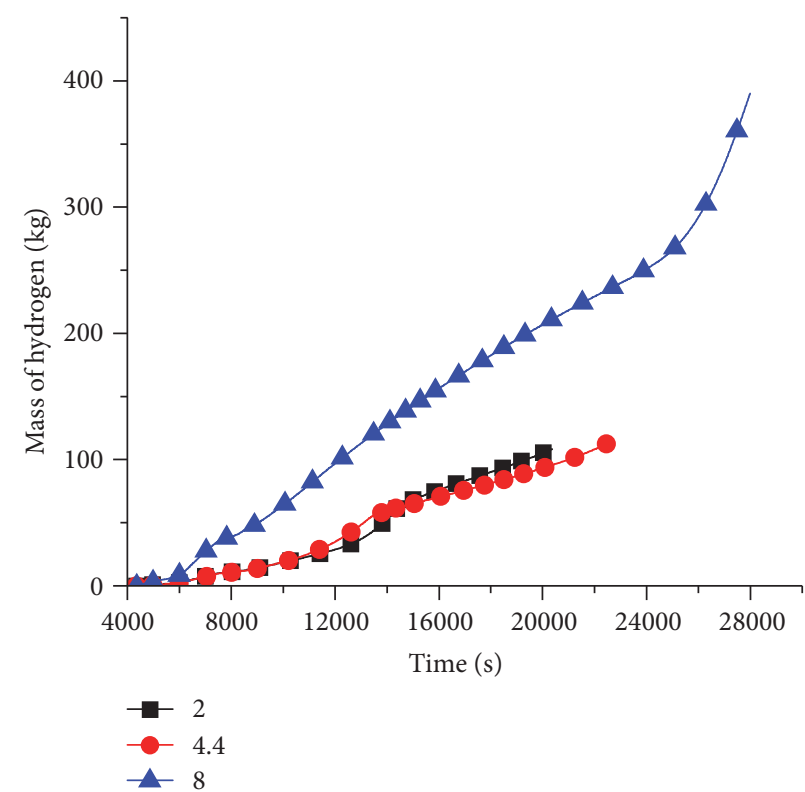

(a) Mass

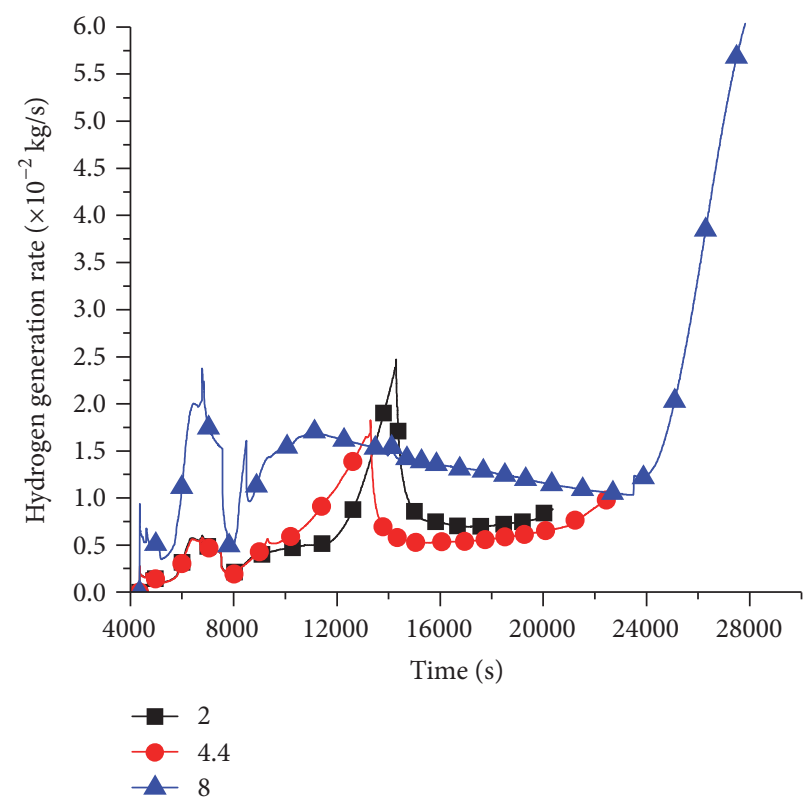

(b) Hydrogen generation rate

FIGURE 13: Hydrogen mass and generation rate under different contents of $\mathrm{H}_{2} \mathrm{O}$.

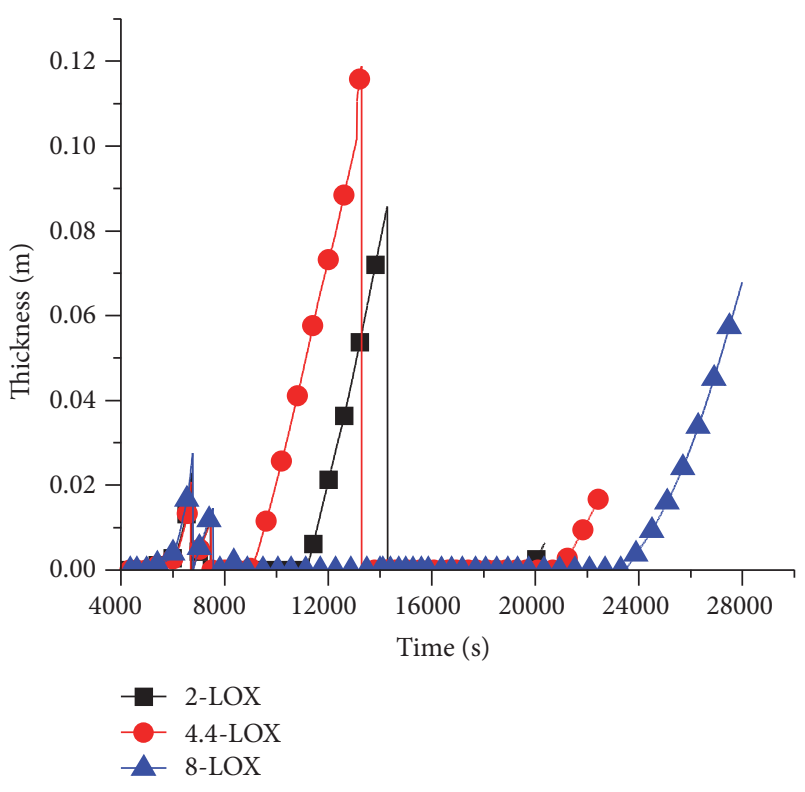

FIGURE 14: Thickness of LOX under different contents of $\mathrm{H}_{2} \mathrm{O}$.

EPR is examined upon a typical small break loss of coolant severe accident. Relevant parameters are discussed, including the sacrificial concrete ablation rate, the temperature of the melt, and the mass and generation rate of hydrogen. Some general conclusions can be drawn as follows:

(1) As the sacrificial concrete ablation enthalpy increases, its ablation rate decreases, and meanwhile the meltthrough time of basemat increases. With the higher sacrificial concrete ablation enthalpy, the hydrogen generation rate is lower, and the temperature

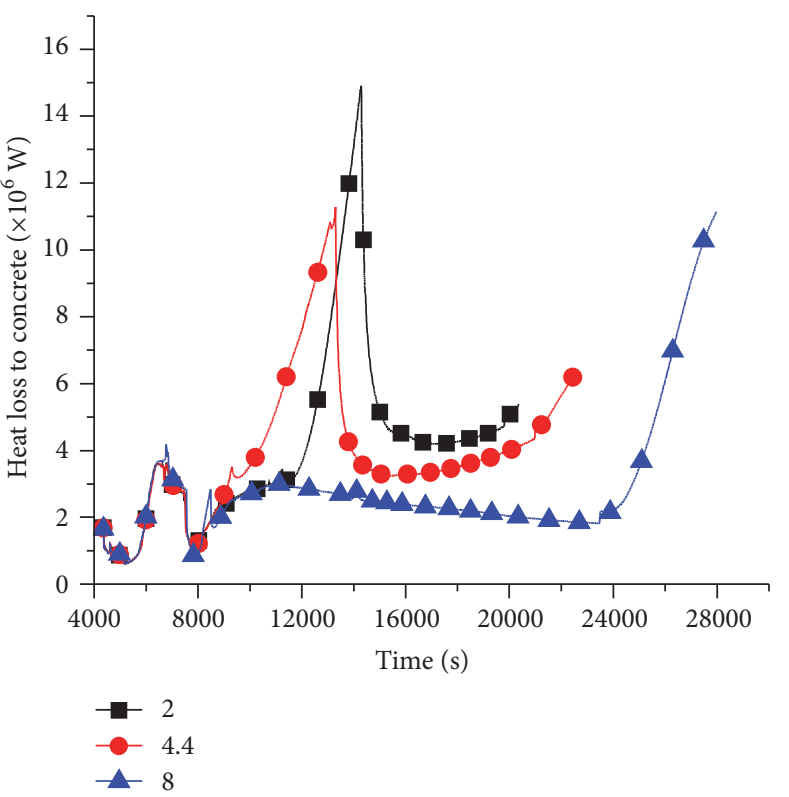

FIgURE 15: Heat loss to sacrificial concrete under different contents of $\mathrm{H}_{2} \mathrm{O}$.

decreases faster. Besides that, little difference can be detected in the total hydrogen mass.

(2) The higher $\mathrm{Fe}_{2} \mathrm{O}_{3}$ content leads to the larger ablation rate as well as hydrogen generation rate, but little difference exists for the total masses of hydrogen. A faster decrease of temperature is detected at the melt pool. 


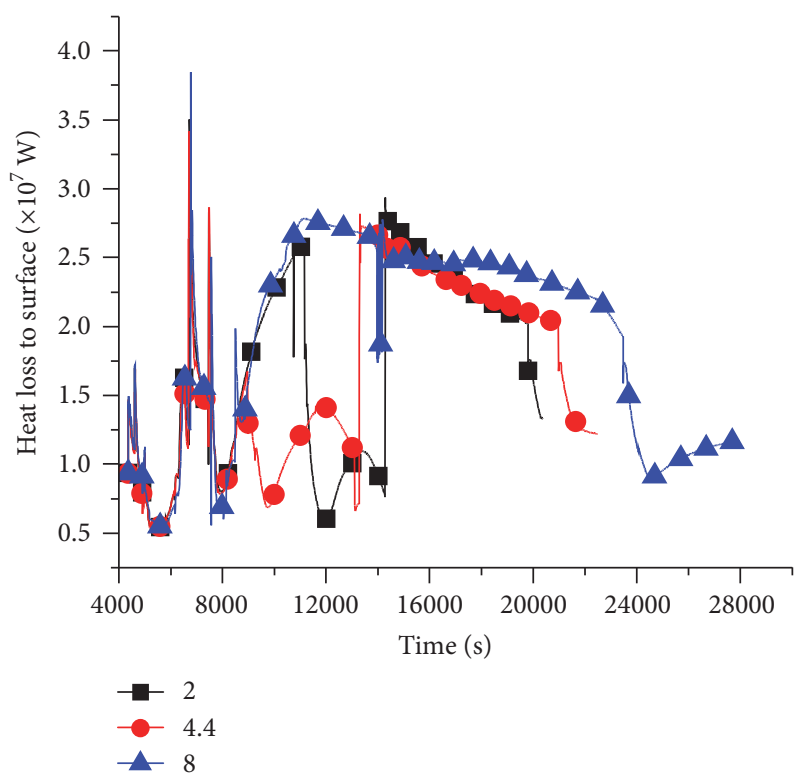

Figure 16: Heat loss to surface under different contents of $\mathrm{H}_{2} \mathrm{O}$.

(3) When LOX appears in the melt, the sacrificial concrete ablation rate increases rapidly. The quick decrease of heat to the surface results in the sharp increase of heat transmitted to sacrificial concrete. Most of all, the ablation rate of sacrificial concrete decreases with the increased $\mathrm{H}_{2} \mathrm{O}$ content. Compared with the $2 \% \mathrm{H}_{2} \mathrm{O}$ content, the melt-through time and total hydrogen mass for the $8 \% \mathrm{H}_{2} \mathrm{O}$ content are 0.48 and 2.6 times larger, respectively.

(4) In practice, the ablation enthalpy of sacrificial concrete is the higher the better, while the $\mathrm{Fe}_{2} \mathrm{O}_{3}$ and $\mathrm{H}_{2} \mathrm{O}$ content of sacrificial concrete is the lower the better.

(5) The simulation study has significant consulting meaning to the mix proportion design of the ferrosiliceous sacrificial concrete.

\section{Competing Interests}

The authors declare that there is no conflict of interests regarding the publication of this paper.

\section{Acknowledgments}

The investigation is finically supported by China National Natural Science Funding Committee (nos. 51378114 and 5161113020), National Basic Research Program of China (973 program, 2015CB655105), and Transformation of Major Scientific and Technological Achievements of Jiangsu Province Funded Projects (no. 85120000220), which are gratefully appreciated.

\section{References}

[1] T. Sevón, T. Kinnunen, J. Virta, S. Holmström, T. Kekki, and I. Lindholm, "HECLA experiments on interaction between metallic melt and hematite-containing concrete," Nuclear Engineering and Design, vol. 240, no. 10, pp. 3586-3593, 2010.

[2] T. Sevón, C. Journeau, and L. Ferry, "VULCANO VB-U7 experiment on interaction between oxidic corium and hematitecontaining concrete," Annals of Nuclear Energy, vol. 59, no. 9, pp. 224-229, 2013.

[3] B. Eppinger, F. Fellmoser, G. Fieg, H. Massier, and G. Stern, "Experiments on concrete erosion by a corium melt in the EPR reactor cavity: KAPOOL 6-8," Forschungszentrum Karlsruhe Technik und Umwelt Wissenschaftliche Berichte FZKA 6453, 2000.

[4] W. Widmann, M. Bürger, G. Lohnert, H. Alsmeyer, and W. Tromm, "Experimental and theoretical investigations on the COMET concept for ex-vessel core melt retention," Nuclear Engineering and Design, vol. 236, no. 19-21, pp. 2304-2327, 2006.

[5] M. T. Farmer, S. Lomperski, D. J. Kilsdonk, R. W. Aeschlimann, and S. Basu, "OECD MCCI project 2-D core concrete interaction (CCI) tests: CCI-3 test data report-thermal hydraulic results. Rev. 0 October 15, 2005," Transactions of the Royal Entomological Society of London, vol. 11, no. 1, pp. 715-721, 2005.

[6] C. Journeau, P. Piluso, J.-F. Haquet et al., "Two-dimensional interaction of oxidic corium with concretes: The VULCANO VB test series," Annals of Nuclear Energy, vol. 36, no. 10, pp. 1597-1613, 2009.

[7] M. Fischer, "The severe accident mitigation concept and the design measures for core melt retention of the European Pressurized Reactor," Nuclear Engineering and Design, vol. 230, no. 1-3, pp. 169-180, 2004.

[8] H.-Y. Chu, J.-Y. Jiang, W. Sun, and M. Zhang, "Thermal behavior of siliceous and ferro-siliceous sacrificial concrete subjected to elevated temperatures," Materials and Design, vol. 95, pp. 470480, 2016.

[9] H. Chu, J. Jiang, W. Sun, and M. Zhang, "Mechanical and physicochemical properties of ferro-siliceous concrete subjected to elevated temperatures," Construction and Building Materials, vol. 122, pp. 743-752, 2016.

[10] J. Wang, Y. Zhang, K. Mao et al., "MELCOR simulation of core thermal response during a station blackout initiated severe accident in China pressurized reactor (CPR1000)," Progress in Nuclear Energy, vol. 81, pp. 6-15, 2015.

[11] M. Nie, Temporary Melt Retention in the Reactor Pit of the European Pressurized Water Reactor (EPR), 2005.

[12] R. O. Gaunt, R. K. Cole, C. M. Erickson et al., MELCOR Computer Code Manuals: Primer and Users' Guides Version 1.8.5, NUREG/CR-6119, SAND2000-2417/1, vol. 1, 1994.

[13] T. Sevon, Molten Core-Concrete Interactions in Nuclear Accidents: Theory and Design of an Experimental Facility, 2005.

[14] D. R. Bradley, D. R. Gardner, J. E. Brockmann, and R. O. Griffith, Corcon-mod3: An Integrated Computer Model for Analysis of Molten Core-concrete Interactions. User's Manual, Nuclear Fuel Cycle and Fuel Materials, 1993.

[15] G. A. Greene, "Heat, mass, and momentum transfer in a multifluid bubbling pool," Advances in Heat Transfer, vol. 21, pp. 277-346, 1991.

[16] S. S. Kutateladze and I. G. Malenkov, "Boiling and bubbling heat transfer between a gas-liquid system and a heat exchange element," Journal of Applied Chemistry of the USSR, vol. 35, no. 11, 1962.

[17] L. Tong, X. Cao, J. Li, and Y. Yang, "Model comparisons on molten core-concrete interactions," Nuclear Science and Techniques, vol. 20, pp. 251-256, 2009. 
[18] M. Nie, "Sacrificial concrete layer thickness in the core catcher," Tech. Rep., Revision A, Framatome ANP, 2004.

[19] R. Gencheva, A. Stefanova, and P. Groudev, "ASTECv2/ MEDICIS computer code investigation of influence of water content and carbon dioxide content in the concrete on the kinetics of molten corium-concrete interaction," Nuclear Engineering and Design, vol. 265, pp. 625-632, 2013.

[20] P. Dejardin and L. Sallus, "Parametrical study on MCCI reactor cases under dry cavity conditions for assessment of parameters of importance," in Proceedings of the 5th European Review Meeting on Severe Accident Research (ERMSAR '12), Cologne, Germany, March 2012. 

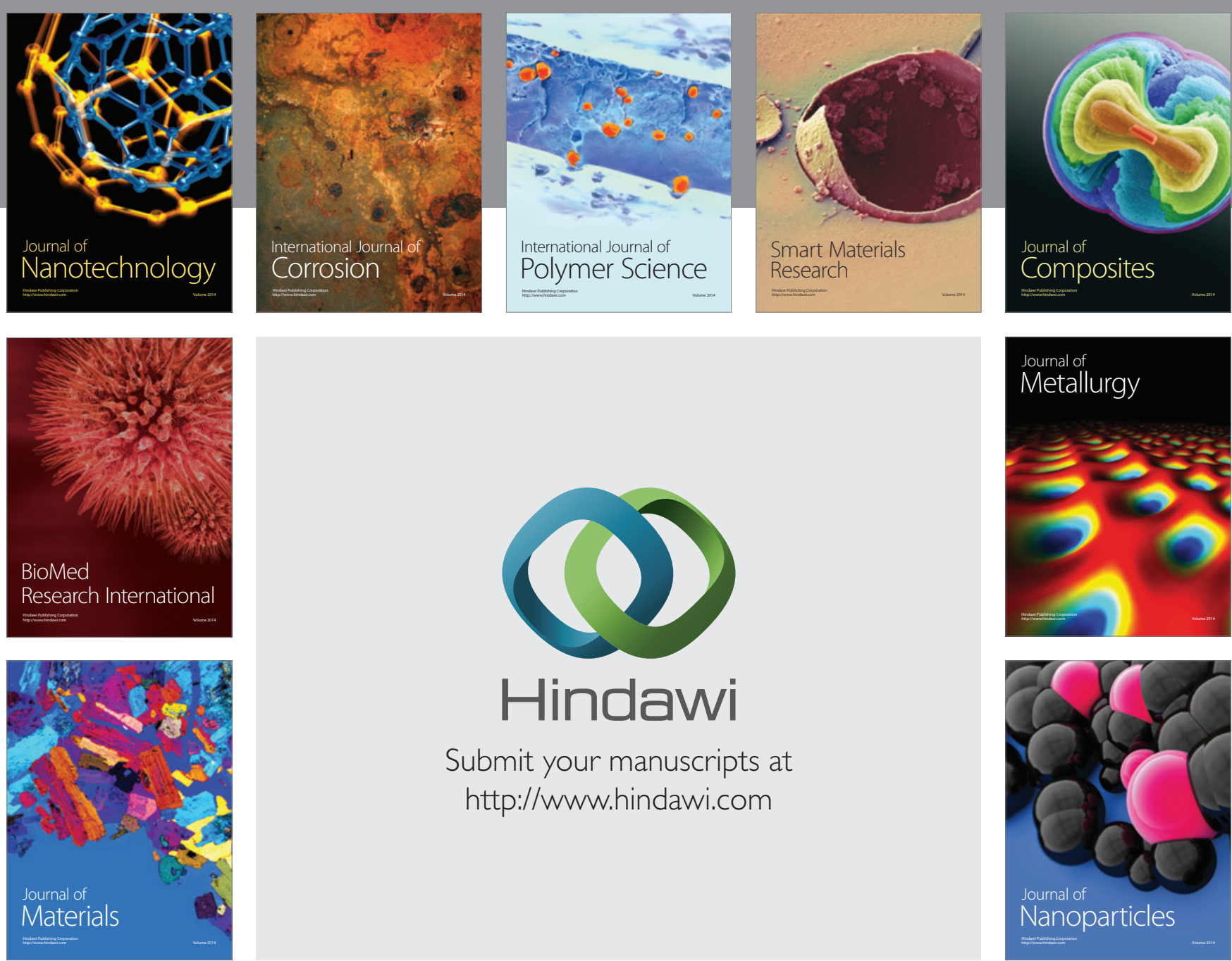

\section{Hindawi}

Submit your manuscripts at

http://www.hindawi.com

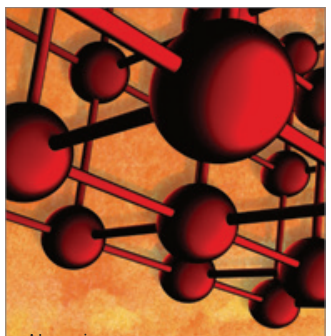

Materials Science and Engineering
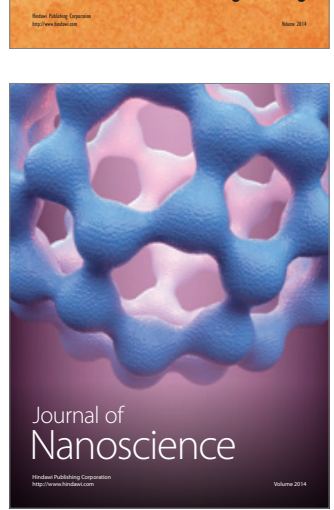
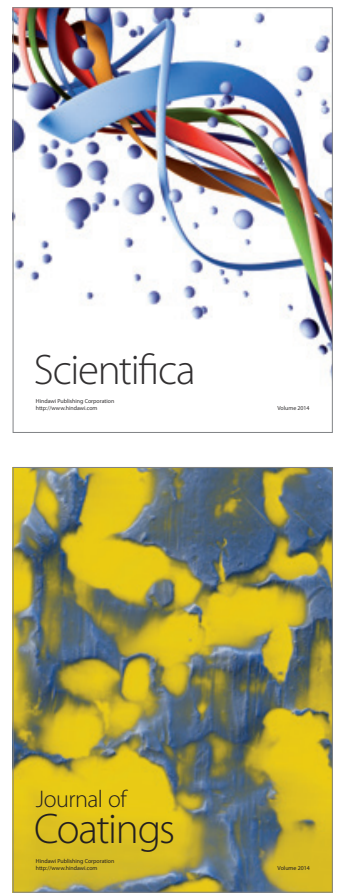
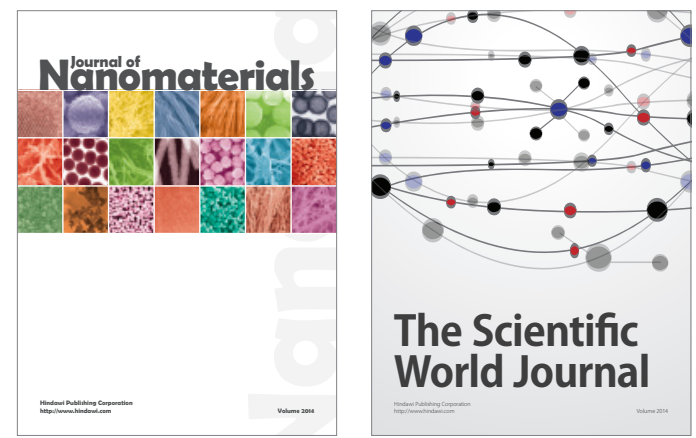

The Scientific World Journal
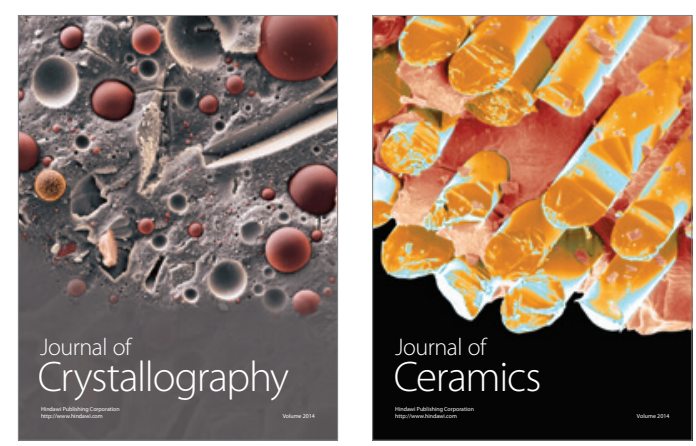
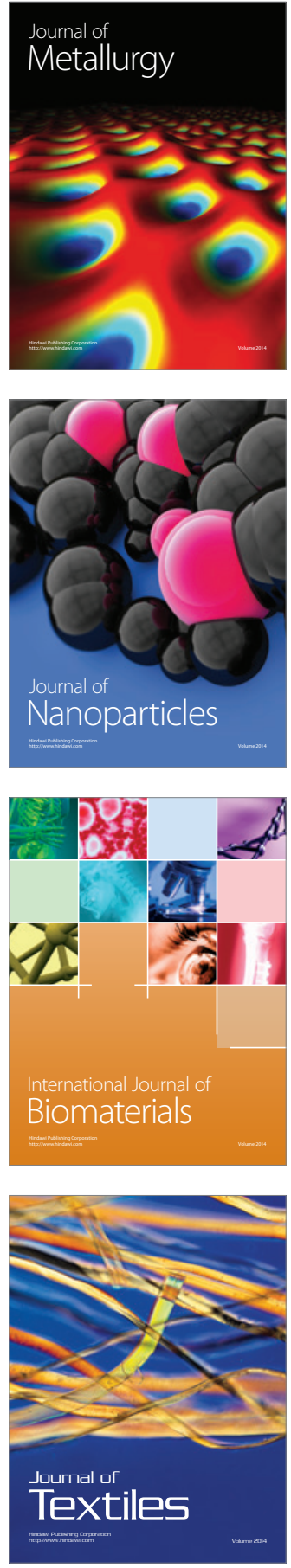